\title{
Producers' access to agricultural credit in Turkey: the case of Adana province
}

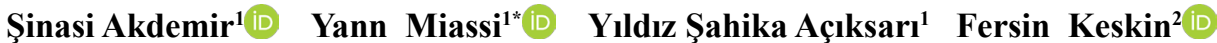 \\ ${ }^{1}$ Department of Agricultural Economics, University of Cukurova, 01330, Adana, Turkey. E-mail: yannmanu006@gmail.com. *Corresponding author. \\ ${ }^{2}$ Ministry of Agriculture and Livestock, Ankara, Turkey.
}

\begin{abstract}
The issue of producers' access to agricultural credit is the key word in contemporary debates in the sense that this theme is increasingly addressed at conferences and scientific congresses. This is explained by the fact that agricultural credit is today considered as an important key to the development of the agricultural sector in developing countries. This study examined the factors influencing producers access to agricultural credit in Turkey, precisely in the province of Adana. Questionnaire-based surveys were conducted on a sample of 101 producers trained in a simple random. From the analysis of the results obtained, we deduced that socio-economic factors such as the total area of land used, the irrigated area, the ratio between the total share of land used and the total owned land, then the ratio between the number of agricultural assets of the household and the total number household members play a preponderant role in the access of producers to agricultural credit. Since agricultural credit is perceived as an important lever in terms of the development of the agricultural sector in Turkey; it is therefore imperative, based on these research results, to develop policies aiming to improve producers' access to agricultural credit. Key words: agricultural credit, determining factors, socio-economic factors, Turkey.
\end{abstract}

Fatores que determinam o acesso dos produtores ao crédito agrícola na Turquia: o caso da província de Adana

RESUMO: A questão do acesso dos produtores ao crédito agrícola é palavra-chave nos debates contemporâneos, na medida em que este tema é cada vez mais abordado em conferências e congressos cientificos. Isso se explica pelo fato de que o crédito agrícola é hoje considerado uma importante chave para o desenvolvimento do setor agricola nos países em desenvolvimento. Este estudo examina os fatores que influenciam o acesso dos produtores ao crédito agrícola na Turquia, precisamente na província de Adana. Pesquisas baseadas em questionário foram realizadas em uma amostra de 101 produtores treinados de forma aleatória simples. A partir da análise dos resultados obtidos, deduzimos que fatores socioeconômicos como a área total de terra usada, a área irrigada, a proporção entre a parcela total de terra usada e o total de terras possuídas, então a proporção entre o número de ativos agrícolas da família e o número total de membros da família desempenham um papel preponderante no acesso dos produtores ao crédito agrícola. Como o crédito agrícola é percebido como uma alavanca importante em termos de desenvolvimento do setor agrícola na Turquia, é, portanto, imperativo, com base nesses resultados da pesquisa, desenvolver políticas destinadas a melhorar o acesso dos produtores ao crédito agrícola.

Palavras-chave: crédito agricola, fatores determinantes, fatores socioeconômicos, Turquia.

\section{INTRODUCTION}

The agricultural sector, considered to be essential for the development and well-being of all countries, consists mainly of rural populations (FARAH, 2018). These populations, most of whom have low sources of income, engage in small-scale agricultural activity (FAO et al., 2017). This is the case of the rural population of Turkey, characterized by a multitude of small family farms that are highly fragmented with an insufficient level of agricultural investment (GURSEL et al., 2017).

Despite the potentialities (the richness of its soils, its resources in cultivable land, water and its relief) that the country has to produce different varieties of agricultural products, Turkey is unable to face the competition of many products of European Union (OZLEM, 2009). This is explained by the low development of arable land leading to the poor diversification of agricultural products with the major reason being the liquidity constraint at the producer level. Producers between sowing, harvesting and marketing need cash flow to finance the activities of the agricultural campaign and acquire agricultural materials and equipment.

Unfortunately, the equity capital mobilized by producers is low, which does not allow them to finance their activity (PHUNG, 2010). The need for financing agricultural activities is; therefore, significant. According to FAO and GTZ (2000), there 
are two main sources of producer finance: the formal source and the informal source. The formal system brings together all the services offered by banks, microfinance institutions and agricultural credit cooperatives. Banks, microfinance institutions and cooperative associations are formal credit providers (YAVUZ et al. 2000). The informal system, for its part, brings together all other forms of financing, particularly loans between individuals, rotating tontines and mutual aid often applied by small farms because their access to formal credit institutions is limited (TANRIVERMIS \& BAYANER, 2006). The fact remains that both of these forms of financing are of some importance to producers. Agricultural financing will not only allow the development of the agricultural sector through optimal use of production factors (improved seeds, fertilizers, pesticides, etc.) in quantity and quality at the right time, increasing the area planted, agricultural mechanization, the improvement of productivity but also will allow the improvement of producers' incomes and the increase of the country's GDP (SOSSOU, 2015). All this implies appropriate financing needs, the granting of substantial credits and good financial management on the part of producers. However, financial institutions are not the only source of funding for producers. It may also be the desire to get the producer to save his income by himself (MOULENDE FOUDA, 2003).

It is for this purpose that this article consists in determining the factors likely to influence the access to agricultural credit of producers in the province of Adana. There are several Scientifics works such as those of HAYRAN \& GUL, (2018), then of BERK (2019) who subscribed to this dynamic but very few of them focused on producers living in the city center. The effects of socio-economic factors such as age, household size and income on access to agricultural credit are well known in the literature (NGUYEN \& LE, 2015). According to LIN et al (2019), they reported that non-farm businesses reduced the demand for credit in rural areas of China. The number of adults in the household increases the labor force available to the farm. Hence, it increases the loan demand in order to tap the available labor force. In addition, according to SHAH et al. (2008), households with more adults tend to participate more in the formal loan, as this increases their confidence to repay the loan. LORE (2007), showed that the age of the producer influences his access to credit. The same author asserted that the age of the producer is indicative of a useful experience of self-selection in the credit market. The literature has emphasized the importance of the number of years of experience as a producer in credit markets (NGUYEN \& LE, 2015). In Pakistan, the most important factor for farmers' access to agricultural credit is land ownership (KOSGEY, 2013; SALEEM et al., 2014). Research has revealed the relationship between farmers 'land ownership and producers' access to credit (KOSGEY, 2013; NGUYEN \& LE, 2015).

Unlike previous research, this study focused mainly on producers living in the city center as well as the outskirts of the city of Adana. Based on the parameters identified it is considered that producers' access to agricultural credit will improve.

\section{MATERIALS AND METHODS}

Considering the time and the means at our disposal, this study randomly focused on 101 producers living in downtown Adana province who have farms in rural areas. The choice of these producers was made in order to obtain a representative sample of the population. The 101 producers were chosen so that there are producers of all social classes. There are large producers as well as medium and small producers. The questionnaire was used to collect information during the first quarter of 2020. Several studies such as those of ERDAS (2012), HAYRAN \& GUL (2018), then that of BERK (2019) have analyzed the factors influencing the use of agricultural credit by producers in Turkey using Logistic or Probit regression models. These models consisted in making the model dependent variable a binary variable coded by " 0 " when the producer did not use agricultural credit and then by " 1 " otherwise. With a view to diversifying analytical tools, this study has rather relied on the research of SAQIB et al. (2017) who carried the same study in Pakistan. To this end, a multiple linear regression model based on the Ordinary Least Squares (OLS) method was carried out in order to identify and analyze the factors influencing the recourse of producers in the province of Adana to agricultural credit. The data collected focused on the socio-economic characteristics of producers. The model's dependent variable was producers' access to agricultural credit. This variable was measured as the ratio between the amount of credit received by producers and the size of their land ownership. This variable is specified by equation (1): $y_{i j}=\frac{\text { Proportion of credit recieved by farmers to total credit }}{\text { Proportion of landholding of farmers to total landholding }}$

where $y_{i j}$ denotes the producer's access to credit; $i$ represents an agricultural household and then $j$ designates a formal or informal source of credit.

The choice of independent variables was made on the basis of studies previously carried out 
on the topic. The independent variables of the model are: the age of the producer, the number of years of schooling, the size of the household, the total area of land used, the area irrigated, the ratio between the total share of land used and the total land owned, then the ratio between the number of farm assets in the household and the total number of household members.

Based on the studies of TOVIGNAN et al. (2018) and then of MIASSI et al. (2020), the multiple linear regression can be written as follows:

$Y=\alpha_{0}+\alpha_{1} \mathrm{X}_{i}+\varepsilon_{i}$

Where: $Y$ is the dependent variable, $\mathrm{X} i$ the independent variables, $\alpha$ is the observation and $\varepsilon_{i}$ the error term of the model.

All of the study variables were reported in Table 1. SPSS software was used as the data processing and analysis software.

\section{RESULTS AND DISCUSSION}

Socio-economic and demographic characteristics of the producers

The socio-economic and demographic characteristics of the producers who were surveyed are reported in table 2 .

Producers in Adana Province are on average 47 years old with 25 years of seniority in agricultural production. This average age is close to that obtained by HAYRAN \& GUL, (2018). Producers aged 45 to 54 represent a large share of the population (60.4\%). Households have an average of 4 people including 2 agricultural assets. In addition, it should be noted that $48.5 \%$ of producers have a secondary level and about $20 \%$ have a university level. These results corroborated those of BERK (2019). It should also be noted that $64.7 \%$ of producers with a university level are graduates of the faculties of agriculture and veterinary science. $26.7 \%$ of producers have other sources of income besides agriculture. AKDEMIR et al. (2004), having an external source of income allows the producer to better cope with the costs linked to agricultural production. In general, $98 \%$ of producers are personally involved in agricultural operations and only $16.8 \%$ resort to the use of tractors.

Results of the multiple linear regression performed to determine the factors likely to influence producers' access to agricultural credit have been reported in table 3 .

\section{Producers' access to agricultural credit}

Agricultural credit demand for farmers has increased in Turkey and will continue to increase in the future in order to meet short-term needs such as buying inputs and long-term purposes like investing in land, irrigation installations and the acquisition of machinery (GUNES \& MOVASSAGHI, 2017). In developing countries and in Turkey's agricultural credit system has a dual structure: formal and informal. The formal system brings together all the services offered by banks, microfinance institutions and agricultural credit cooperatives (YAVUZ et al. 2000). Banks, microfinance institutions and cooperative associations are formal credit providers. In Turkey, among the banks, there are Ziraat Bank, Tarım Kredi and Iş Bank which grant interest loans to producers according to the speculations produced; producers opting for speculations requiring production inputs obtain the highest credits. These interest rates vary

Table 1 - Variables used in the linear regression model.

\begin{tabular}{|c|c|c|}
\hline Variables & Explanation & Measurement \\
\hline \multicolumn{3}{|c|}{ Dependent variable $\left(Y_{i j}\right)$} \\
\hline Access to credit & Access to credit & $\begin{array}{l}\text { Specified in } \\
\text { equation (1) }\end{array}$ \\
\hline \multicolumn{3}{|c|}{ Independent variable $\left(\mathrm{X}_{i}\right)$} \\
\hline$X_{1}$ Age & Age of producer & In year \\
\hline $\mathrm{X}_{2}$ Schooling & Number of years of schooling & In year \\
\hline $\mathrm{X}_{3}$ Household size & Total number of household members & In number \\
\hline $\mathrm{X}_{4}$ Exploited land & Area exploited & In decar \\
\hline $\mathrm{X}_{5}$ Irrigated land & Area exploited & In decar \\
\hline $\mathrm{X}_{6}$ Ratio 1 & $\begin{array}{l}\text { Ratio between the total share of land used by the producer and the total land } \\
\text { owned }\end{array}$ & Ratio \\
\hline $\mathrm{X}_{7}$ Ratio 2 & $\begin{array}{l}\text { Ratio between the number of agricultural assets in the household and the total } \\
\text { number of household members }\end{array}$ & Ratio \\
\hline
\end{tabular}

Ciência Rural, v.51, n.5, 2021. 
Table 2 - Socio-economic and demographic characteristics of the surveys.

\begin{tabular}{|c|c|c|c|}
\hline \multicolumn{2}{|c|}{ Variables } & \multirow{2}{*}{$\begin{array}{c}\text { Percentage } \\
18.8\end{array}$} & \multirow{2}{*}{$\begin{array}{c}\text { Average } \\
35.7\end{array}$} \\
\hline \multirow{4}{*}{ Age } & $25-44$ & & \\
\hline & $45-54$ & 60.4 & 48.6 \\
\hline & More than 55 & 20.8 & 58.3 \\
\hline & Total & 100.0 & 47.6 \\
\hline \multirow{4}{*}{ Number of years of experience } & $1-20$ & 19.8 & 12.5 \\
\hline & $21-30$ & 55.4 & 27.1 \\
\hline & More than 30 & 24.8 & 37.3 \\
\hline & Total & 100.0 & 25.6 \\
\hline \multirow{4}{*}{ Household size } & $1-2$ & 6.9 & 1.8 \\
\hline & $3-4$ & 66.3 & 3.2 \\
\hline & More than 5 & 26.7 & 6.6 \\
\hline & Total & 100.0 & 3.9 \\
\hline \multirow{4}{*}{ Number of agricultural assets } & 1 & 47.5 & 1.0 \\
\hline & 2 & 25.7 & 2.0 \\
\hline & More than 3 & 26.7 & 3.7 \\
\hline & Total & 100.0 & 2.2 \\
\hline \multirow{4}{*}{ Level of education } & Primary and lower & 34.7 & - \\
\hline & Secondary - High school & 48.5 & - \\
\hline & University & 16.8 & - \\
\hline & Total & 100.0 & - \\
\hline \multirow{3}{*}{ University branch } & Agriculture - veterinarian & 64.7 & - \\
\hline & Other & 35.3 & - \\
\hline & Total & 100.0 & - \\
\hline \multirow{4}{*}{ Profession } & Farmer & 91.1 & - \\
\hline & Merchant - Craftsman & 2.0 & - \\
\hline & Other & 6.9 & - \\
\hline & Total & 100.0 & - \\
\hline \multirow{3}{*}{$\begin{array}{l}\text { Source of income outside } \\
\text { agriculture }\end{array}$} & Yes & 26.7 & - \\
\hline & No & 73.3 & - \\
\hline & Total & 100.0 & - \\
\hline \multirow{3}{*}{ Use of tractor } & Yes & 16.8 & - \\
\hline & No & 83.2 & - \\
\hline & Total & 100.0 & - \\
\hline \multirow{3}{*}{$\begin{array}{l}\text { Personal involvement in } \\
\text { agricultural activities }\end{array}$} & Yes & 98.0 & - \\
\hline & No & 2.0 & - \\
\hline & Total & 100.0 & - \\
\hline
\end{tabular}

Source: Survey result, 2020.

from bank to bank. At the same time, the Turkish government also subsidizes producers registered in the National Register of Producers of Turkey and then organizes the sale of their harvest products.

The informal system, for its part, brings together all other forms of financing, particularly loans between individuals, rotating tontines and mutual aid often applied by small farms because their access to formal credit institutions is limited (TANRIVERMIS \& BAYANER, 2006). Cooperative associations such as Tarım kredi and Kredi koperatif do not provide credit to member producers; but rather provide them with inputs (fertilizers, chemicals, seeds, etc.). Inputs received in the form of a loan are then repaid with interest in cash after sale of the harvest products or in kind with the harvest products.

The regression model performed is globally significant $(\mathrm{P}<0.01)$ then the $\mathrm{R}^{2}$ obtained is 0.834 . In other words, the variables introduced into the model account for $83 \%$ of producers' use of 
Table 3 - Estimation result of the linear regression model.

\begin{tabular}{|c|c|c|c|c|c|}
\hline Variables & Coefficient & Std error & $\mathrm{t}$ & $\mathrm{P}$ & VIF \\
\hline Constant & 0.883 & 0.669 & 1.319 & 0.190 & \\
\hline $\mathrm{X}_{1}$ Age & 0.153 & 0.011 & 1.014 & 0.315 & 8.192 \\
\hline $\mathrm{X}_{2}$ Schooling & 0.006 & 0.023 & 0.043 & 0.966 & 0.131 \\
\hline $\mathrm{X}_{3}$ Household size & 0.05 & 0.031 & 0.388 & 0.700 & 0.167 \\
\hline $\mathrm{X}_{4}$ Exploited land & -0.133 & 0.317 & -1.682 & $0.098^{*}$ & 0.264 \\
\hline $\mathrm{X}_{5}$ Irrigated land & -0.133 & 0.198 & -1.712 & $0.092^{*}$ & 0.249 \\
\hline $\mathrm{X}_{6}$ Ratio 1 & 0.917 & 0.143 & 6.419 & $0.000^{* * *}$ & 3.268 \\
\hline $\mathrm{X}_{7}$ Ratio 2 & 0.870 & 0.243 & 3.580 & $0.001^{* * *}$ & 3.268 \\
\hline \multicolumn{6}{|c|}{$F=150,832$} \\
\hline \multicolumn{6}{|c|}{ Prob $=0,000$} \\
\hline \multicolumn{6}{|c|}{$\mathrm{R}^{2}=0,834$} \\
\hline
\end{tabular}

${ }^{* * *}$ : significant at the $1 \%(\mathrm{P}<0.01) ;{ }^{* *}$ : significant at $5 \%(0.01<\mathrm{P}<0.05) ;{ }^{*}$ : Significant at $10 \%(0.05<\mathrm{P}<0.10)$. Source: Results of estimates made with SPSS.

agricultural credit. Starting from the results of the regression model, we deduce that producers' access to agricultural credit in the province of Adana is determined by: the total area of land used, the area irrigated, the ratio between the total share of land used and the total land held, then by the ratio between the number of agricultural assets in the household and the total number of household members.

Analysis of the results showed that the total area of land used negatively influences producers' access to agricultural credit $(\mathrm{P}<0.10)$. This implied that an increase of one decar of exploited land reduces producers' access to agricultural credit by 0.133 units. Thus, the greater the quantity of land sown by the producer, the less the latter has recourse to agricultural credit. According to AKDEMIR (2012), the plain of the Adana region is characterized by intensive agriculture requiring significant capital contributions. Indeed, large producers manage to generate significant income which enables them to finance their activities by themselves. Large producers are; therefore, financially independent and do not feel the need to use agricultural credit. These results are however contrary to those obtained by AKDEMIR et al. (2019), KUSEK et al. (2018) and HAYRAN \&GUL, (2018) who assessed producers' access to agricultural credit in other regions of Turkey. There is; therefore, a peculiarity in the province of Adana. According to SAQIB et al. (2017), in Pakistan, large producers are those most in need of agricultural credit. Only small producers, given their low income, feel in certain circumstances obliged to take out agricultural credit in order to carry out agricultural operations.
In most cases, small farmers apply for agricultural credit to purchase seeds, fertilizers and pesticides (HUSSAIN \& THAPA, 2012).

Like the variable total area of land used, the area irrigated by the producer also has a negative impact on producers' access to agricultural credit ( $\mathrm{P}$ $<0.10$ ). As a result, an increase in a decar of irrigated land reduces producers' access to agricultural credit by 0.133 units. Indeed, water is an essential element for agricultural production (COPA-COGECA, 2010). This result is explained by the fact that producers opting for an agriculture based on extensive irrigation systems manage to maximize the income from their exploitation. This allows them to easily self-finance their activities.

Unlike the two previous variables, the variable ratio between the total share of exploited land and the total of land held positively influences producers' access to agricultural credit $(\mathrm{P}<0.01)$. Consequently, the higher this ratio (close to 1), the more the producer is ready to use agricultural credit. In other words, the closer the area exploited to the total area of land owned by the producer, the better he has access to agricultural credit. Indeed, the producer is more motivated to invest in the land when it belongs to him. In this context, he feels more the interest to contract a loan in order to diversify the activities of his exploitation. At the same time, note that the area of land belonging to a producer or a household is one of the criteria for defining the status or social class of membership of the producer or household. This criterion is of great importance in Turkey (DEMIRCI et al., 2007). The more land the producer holds, 
the more he is eligible to contract the credit; in the sense that it can pledge or mortgage a significant amount of land. These results corroborated with those of BAFFOE \& MATSUDA (2015) and then of DZADZE et al. (2012).

The analysis results also showed that the variable ratio between the number of agricultural assets in the household and the total number of household members has a positive impact on the producer's access to agricultural credit $(\mathrm{P}<0.01)$. As a result, the higher this ratio (close to 1), the better the producer is able to use agricultural credit. In other words, when the number of agricultural assets in the household is close to the total number of household members, the producer is more willing to use agricultural credit. In agriculture, the main factors of production are: land, labor and capital. The more active the family members, the more labor the producer has. According to $\mathrm{OBOH} \&$ EKPEBU (2011) then SEBOPETJI \& BELETE (2009), the size of the producer's household has a positive impact on his decision to use agricultural credit. Thus, with a view to maximizing the use of the labor force at his disposal, the producer registers with a view to seeking credit for the acquisition of land. This also allows the producer to relax his operation.

In the province of Adana, there are several financial services including banks, cooperatives as well as microfinance structures that provide loans to producers so that they can carry out their agricultural activities. Given the fact that characteristics and conditions of close grant are decisive in producers' access to agricultural credit, the producers surveyed were asked to evaluate the financial services operating in the province of Adana. This evaluation focused on certain criteria such as: the interest rate fixed, the procedure and formalities for granting the credit, the amount granted, the terms and time of payment, then the mortgages.

To this end, producers were asked to assign scores for each of the criteria. Scores were assigned on a scale from 1 to 5 . Score 1 is given when the service is poor and 5 when it is good. Subsequently, general score averages were calculated to identify the financial services offering the best services in the province of Adana.

Analysis of these figures shows that banks are the financial services that play the most role in terms of granting agricultural credit to producers in the province of Adana. Based on the scores assigned by criteria, we deduce that Ziraat Bank is the bank offering the best services to producers (Figure 1). According to KUSEK et al. (2017), Ziraat Bank one of the most important players in the agricultural credit market in Turkey. Results in Figure 2 also confirmed this result in that Ziraat Bank obtained the highest score (3.94). Besides Ziraat Bank, Tarım Kredi and Iş Bank also offer one of the best services with scores of 2.76 and 2.06 respectively.

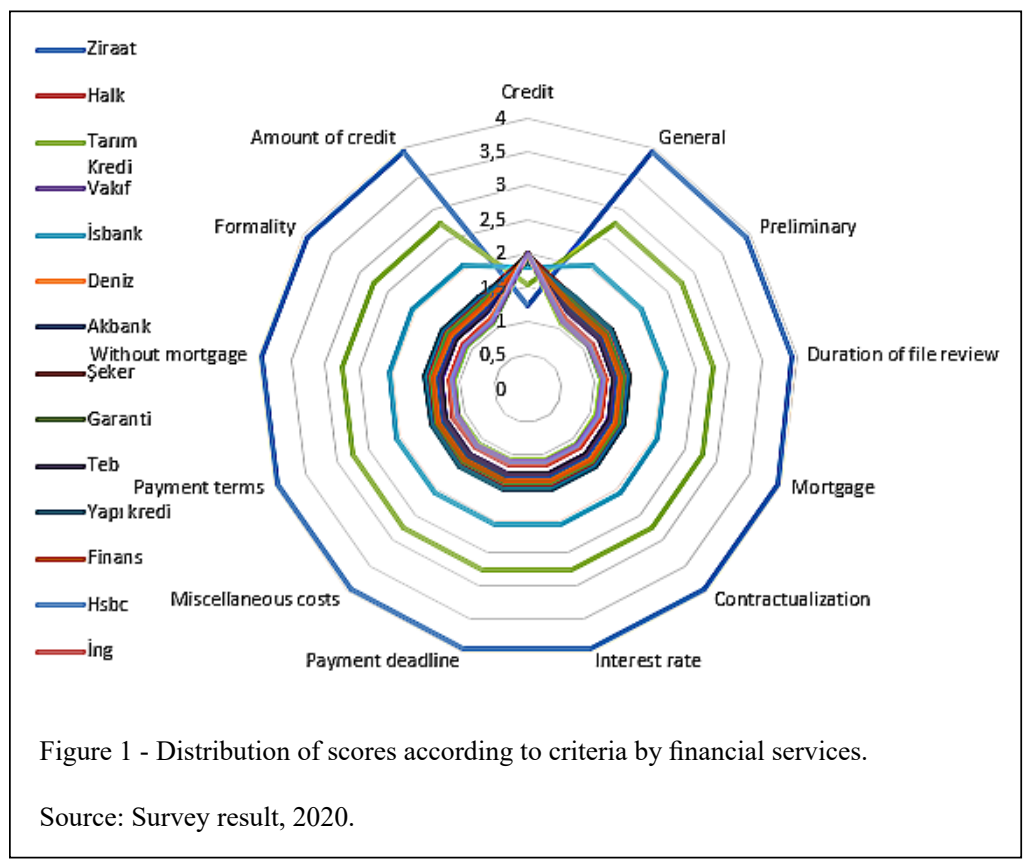

Ciência Rural, v.51, n.5, 2021. 


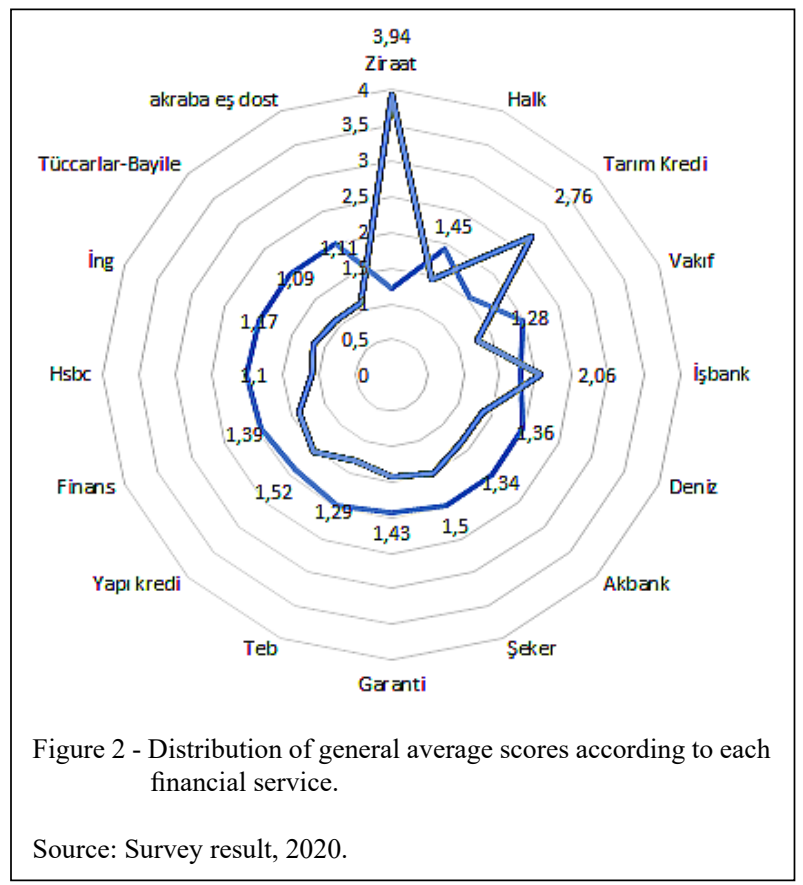

Figure 1 shows the distribution of scores according to the criteria and then the different financial services. Figure 2 shows the general average scores according to each financial service.

\section{CONCLUSION}

The main objective of this study was to analyze the factors that may influence access to agricultural credit for producers in the province of Adana. Analysis of the results shows that socioeconomic and demographic factors have a significant impact on producers' access to agricultural credit. These include: the total area of land used, the area irrigated, the ratio between the total share of land used and the total owned land, then the ratio between the number of agricultural assets of the household and the total number household members. It should also be noted that in the province of Adana, financial services such as Ziraat Bank, Tarım Kredi and Iş Bank are offering the best services to producers. Given the importance of agricultural credit for the development of the agricultural sector in Turkey, it is important to put in place policies such as reduced administrative formalities in order to facilitate access for agricultural credit producers. However, this study did not assess the determinants of producers' access to agricultural credit depending on the type of financing used by producers. The next research studies can be part of this dynamic.

\section{BIOETHICS AND COMMITTEE APPROVAL}

We authors of the article entitled "Factors determining producers' access to agricultural credit in Turkey: The case of Adana province" declared, for all due purposes, the project that gave rise to the present data of the same has not been submitted for evaluation to the Ethics Committee of the University /Research Institute " Cukurova University", but we are aware of the contents of Resolution No. 466, of December 12, 2012 of the Brazilian National Health Council "http://conselho.saude.gov.br/resolucoes/2012/ Reso466.pdf" if it involves human. Thus, the authors assume full responsibility for the presented data and are available for possible questions, should they be required by the competent authorities.

\section{DECLARATION OF CONFLICTS OF INTERESTS}

The authors declare no conflict of interest. The founding sponsors had no role in the design of the study; in the collection, analyses, or interpretation of data; in the writing of the manuscript, and in the decision to publish the results.

\section{AUTHORS' CONTRIBUTIONS}

All authors contributed equally to the design and writing the manuscript. All authors also revised the manuscript and then approved the final version.

\section{REFERENCES}

AKDEMIR, S. Problems of financing and agricultural credit: A case study of Seyhan region. Journal of Food, Agriculture and

Ciência Rural, v.51, n.5, 2021. 
Environment, 10(3-4), pp.132-139. 2012.Available from: $<$ https:// www.wflpublisher.com/Abstract/3459>. Accessed: Jan. 25, 2020.

AKDEMIR, S., et al. Institutions et organisation du développement rural, Agriculture et alimentation en Méditerranée. Les défis de la mondialisation. CIHEAM, Lyon, France, 1 p. 2004.

AKDEMIR, S., et al. Factors effecting the credit use of Farmers: Sample of Subprovince of Tarsus, Province of Mersin. Fresenius Environmental Bulletin, 28, pp.4729-4734. 2019. Available from: $<$ https://www.prt-parlar.de/download feb 2019/>. Accessed: Jan. 05,2020 .

BAFFOE, G., MATSUDA, H. Understanding the determinants of rural credit accessibility: The case of ehiaminchini, Fanteakwa District, Ghana. Journal of Sustainable Development, 8(6), pp. 183 - 195. 2015. Available from: <http://www.ccsenet.org/journal/ index.php/jsd/article/view/47599>. Accessed: Jan. 13, 2020.

BERK, A. Determination of factors affecting agricultural credit usage decisions of farmers in Niğde and Karaman provinces. Turkish Journal of Agriculture - Food Science and Technology, 7(8): 1182-1188.2019. Available from: <https://doi.org/10.24925/ turjaf.v7i8.1182-1188.2619>. Accessed: Feb. 03, 2020.

COPA-COGEA. Documents du Copa-Cogeca sur le changement climatique : L'eau et l'agriculture dans le contexte du changement climatique, Fiche technique, 4 p.2010.

DEMIRCI, R., et al. Türkiye'de arazi yönetimive piyasası: temel özellikleri,yasal ve kurumsal düzenlemeler, sorunlar ve değerleme çalışmaları üzerine etkileri. Üçüncü Sektör Kooperatifçilik, 4(42), pp.38 - 63. 2007.

DZADZE, P., et al. Factors determining access to formal credit in Ghana: A case study of smallholder farmers in the AburaAsebu Kwamankese district of central region of Ghana. Journal of Development and Agricultural Economics, 4(14), pp.416423. 2012.Available from: <https://academicjournals.org/journal/ JDAE/article-stat/976722E44653>. Accessed: Jan. 05, 2020.

ERDAS, H. Türkiye'de tarimin finansmaninda banka kredilerinin rolü: Edirne bölgesi örnegi, Doktora Tezi, Tarım Ekonomisi Anabilim Dalı, Namik Kemal Üniversitesi, 152 p.2012

FAO; GTZ. Nouveau regard sur le financement agricole : pourquoi ? $\mathrm{N}^{\circ} 1,59 \mathrm{p} .2000$

FAO et al. Étude sur l'agriculture familiale à petite échelle au Proche-Orient et Afrique du Nord. Pays focus: Tunisie, 186p. 2017. Available from: <http://www.fao.org/3/b-i6436f.pdf> Accessed: Jan. 05, 2020.

FARAH, S. B. Evaluation de l'efficacité technique des exploitations oléicoles en Tunisie : Cas de Chbika, Maitrise en agroéconomie, Université de Laval, Québec, Canada, 181p. 2018.

GUNES, E., MOVASSAGHI, H. Agricultural credit market and farmers' response: a case study of Turkey. Turkish Journal of Agriculture, 5(1): 84. 2017. DOI: 10.24925/turjaf.v5i1.84-92.951.

HAYRAN, S., GÜL, A. Mersin ilinde çiftçilerin tarımsal kredi kullanım kararlarını etkileyen faktörler. Iğdır Univ. J. Inst. Sci. \& Tech. 8(1), pp.271-277. 2018. Available from: <http://dergipark. org.tr/tr/pub/jist/issue/36128/407885>. Accessed: Jan. 02, 2020.
HUSSAIN, A., THAPA, G. B. Smallholders' access to agricultural credit in Pakistan. Food Security, 4(1), pp. 73-85. 2012. Available from: $\quad<$ https://www.researchgate.net/publication/257788763 Smallholders\%27 access to agricultural credit in Pakistan $>$. Accessed: Jan. 05, 2020

KUSEK, G., et al. Structural characteristics of the agricultural sector in terms of access to agricultural credits in Turkey. New Medit, N.4, pp.66-72. 2017.Available from: <https://www.iamm.ciheam. org/ress_doc/opac_css/index.php?lvl=notice_display\&id=38504>. Accessed: Feb. 18, 2020.

KUSEK, G., et al. Evaluation of TMO's (Turkish Grain Board) appointment system for procurement. New medit, 17 (1), pp.49-58. 2018. Available from: <https://www.iamm.ciheam.org/ress_doc/opac_css/ index.php?lvl=notice_display\&id=38878 $>$. Accessed: Jan. 05, 2020.

KOSGEY, Y. K. K. Agricultural credit access by grain growers in Uasin-Gishu County, Kenya. IOSR Journal of Economics and Finance, 2(3), pp.36-52. 2013.

LIN, L., et al. Rural credit constraint and informal rural credit accessibility in China. Sustainability, 11, 1935. 2019.

LORE, M. An evaluation of human capital factors that can enhance access to credit among retailers in Nairobi. Unpublished Project Report Submitted to United states International UniversityAfrica. Nairobi. 2007

MOULENDE FOUDA, T., Les mécanismes de financement en milieu rural camerounais: Une analyse des déterminants de la demande de services financiers des ménages, Université de Versailles Saint-Quentin-en-Yvelines, Centre d'Economie et d'Ethique pour l'Environnement et le Développement (C3ED), 379p.2003. Available from: <https://www.documentation.ird.fr/ hor/fdi:010032197>. Accessed: Jan. 09, 2020.

NGUYEN, T. D., LE, H. T. Enhancing formal credit accessibility of pig production households in Thai Binh province, Vietnam. International Journal of Economics, Commerce and Management, 3(4), pp.1-15. 2015.

OBOH, V. U., EKPEBU, I. D. Determinants of formal agricultural credit allocation to the farm sector by arable crop farmers in Benue State, Nigeria. African Journal of Agricultural Research, 6(1), pp.181-185.2011. Available from: <https://academicjournals.org/ journal/AJAR/article-full-text-pdf/8948EE637453>. Accessed: Jan. 25, 2020

OZLEM, A. Le rôle du secteur agricole turc dans l'économie du pays, Doctorante en économie à l'Université d'Artois et à l'Université Galatasaray, 17p.2009.Available from: $<$ http://gdri. dreem.free.fr/wp-content/f5-1akdere-ozlem colloque texte final. pdf>.Accessed: Jan. 11, 2020.

PHUNG, T. A. Le rationnement du crédit des PME (Le cas du Vietnam), Université Montpellier I, 295p. 2010. Available from: $<$ http://www.theses.fr/2010MON10004>. Accessed: Jan. 05, 2020.

SAQIB, E. S., et al. Factors determining subsistence farmers' access to agricultural credit in flood-prone areas of Pakistan. Kasetsart Journal of Social Sciences. 2017. Available from: $<\mathrm{http}$ ://dx.doi. org/10.1016/j.kjss.2017.06.001>. Accessed: Jan. 05, 2020.

SEBOPETJ, T., BELETE, A. An application of probit analysis to factors affecting small-scale farmers' decision to take credit: A 
case study of the greater Letaba local municipality in South Africa. African Journal of Agricultural Research, 4(8), pp. 718-723. 2009. Available from: $<$ http://citeseerx.ist.psu.edu/viewdoc/download?doi= 10.1.1.902.9420\&rep=rep1\&type=pdf $>$. Accessed: Jan. 11, 2020.

SHAH, S.B., et al. Determination of credit program participation and socioeconomic characteristics of beneficiaries: Evidence from Sargodha. Pak. Inst. Dev. Econ. 47, 94. 2008.

SOSSOU, C. H., Le financement de l'agriculture au Bénin : stratégies de gestion et d'adaptation des exploitations agricoles, communauté française de Belgique, Université de liège - gembloux agro-bio tech, 181p.2015.Available from: $<$ https://orbi.uliege.be/ bitstream/2268/188999/1/SOSSOU_Comlan_Hervé_Version\%20 Définitive-8-12-2015.pdf $>$. Accessed: Feb. 16, 2020.
TANRIVERMIS, H., BAYANER, A. Members' perception and the role of agricultural credit cooperatives in agricultural finance in Turkey. New Medit, N.4, pp.66-72. 2006. Available from: <https://newmedit.iamb.it/share/img_new_ medit_articoli/72_23tanrivermis.pdf $>$.

TOVIGNAN, D. S., et al. Analyzing the determinants of profitability of organic and conventional cotton in Benin. International Journal of Innovation and Scientific Research, (39) 1, pp.79-90. 2018.Available from: <https://orgprints.org/34703/>. Accessed: Jan. 02, 2020

YAVUZ, O., et al. Kırsal Alanda Mikro Tesebbüsler ve MikroFinans, Türkiye IV.Tarım Ekonomisi Kongresi, 6-8 Eylül 2000, Tekirdag. 